\title{
Juridical Study in The Application of the Law About Foster- Child Adoption in Indonesia by Foreign Nationals
}

\author{
Bernadeta Resti Nurhayati ${ }^{*}$, Ignatius Hartyo Purwanto ${ }^{1}$ \\ 1 Universitas Katolik Soegijapranata, Indonesia \\ *e-mail: resti@unika.ac.id
}

Article history: Received 15 December 2020; Accepted 31 March 2021; Available online 30 April 2021

\begin{abstract}
The adoption or adopting transfer of rights to child from authority of parents, legal guardians, or other people who responsible for nurturing, educating, and raise the child to his foster parents family based on law or sentence.

Keywords:

Adoption; Inter-Country Adoption; International Adoption might be conducted to Indonesian children by parents of Indonesian Private Law or even in some special cases, adoption can be conducted by foreign nationals.

The adoption of Indonesian children by foreign nationals is restricted. This is due to the protection of foster-children who adopted by foreign nationals, so that they do not experience unwanted things considering that the child will be taken abroad by the foster parents. Incidents such as children who, after being taken by their foster parents, experience violence or become victims of human trafficking are things that must be considered before deciding to allow the adoption of Indonesian children by foreign nationals.
\end{abstract}

Copyright @ Universitas Pendidikan Ganesha. All rights reserved.

\section{Introduction}

Children are the future of nation. However, the conditions of child's personal life are not always as warm as the expectation. Low income that experienced by parents in economy, often affect the parents' ability to provide living, nurturing, and educating their children. This condition makes parents to give their children to other parties to nurture them so that the child's life will be better than life in poverty.

If there is no other party who is willing to adopt or care for the child, it is possible that the parents take care their child inappropriate, or leave the child on the street. As example, there is case of neglect of five (5) underage children in Cibubur by their parents. This case is only one of the many cases of child neglect in Indonesia. Based on data from the Indonesian Ministry of Social Affairs, by 2014 there were more than four million neglected children in Indonesia. [1]

Adoption is actually only a way to "save" children and their future, so that children can be free from poverty and underprivileged of their parents and have a better future. However, underprivileged is not the only reason for adoption. Based on the perspective of foster parents, adoption is conducted by some reasons, such as: (1) the foster parents have no children; (2) as a bait for foster parents to have children immediately; (3) foster parents do not have children of expected particular gender; and (4) to help children who no longer have parents, or children in orphanages.

Based on the legal system in Indonesia, adoption is not something new. The community has long known adoption that is conducted according to local customs. Iman Sudiyat states that 
adoption can be found in many places in Indonesia, it is an act of taking a child from outsider to relative, so that a social bond is the same as that of biological nationality. [2]

In Indonesia's legal system, there is Law Number 23 of 2002 on the Protection of Children, law that specifically regulates the protection of children in Indonesia, in Article 7 (2) states that: "Due to particular cause so that the parents cannot provide the living and growth of their children, or the children are derelict so that they are permitted to adopt as foster children by other people based on the invitation legislation."

Adoption of children, not only among Indonesian family. Adoption can also be conducted on children of Indonesian nationality by foreign nationals and vice versa.

In the Indonesian legal system, the adoption of Indonesian children by foreign parents is allowing, but with strict conditions, and can only be done as an ultimum remedium. This is due to number of cases of Indonesian children adopted by foreign nationals that end tragically. The case of Tristan Dowse, for example, who was adopted by Irish foster parents, ended tragically, because Tristan, who initially received full attention and care, was later handed over to the orphanage by his foster parents. The case of Tristan Dowse at that time attracted enough attention, because even an Irish court later sentenced Tristan's foster parents. Based on these cases, this study analyzes the application of the law in the case of adoption Indonesian by foreign nationals.

\section{Result and Discussion}

\section{Adoption Arrangements for Children in Indonesia}

The history of adoption arrangements in written Indonesian law starts with the enactment of Staatsblaad 1917 Number 129 (Bepalingen voor geheel Nederlandsch Indie betreffende het Burgerlijk en Handelsrecht van de Chineezen ). The Staatsblaad that manage the enactment of European civil law for the Tiong Hoa group, in its Chapter II contains specific provisions concerning the adoption of children (van adoptie) which were applicable among Chinese Hoa people. Although the current Staatsblaad is no longer valid, this arrangement is an adoption arrangement in written law in Indonesia.

If the Staatsblaad applies to the Tiong Hoa group, then Europeans do not recognize adoption from the beginning. Whereas for indigenous peoples in the practice of adoption, customary provisions in customary law apply. The adoption system, which is considered to have a religionmagical nature, and also conducted in clear and cash manner according to the habits in indigenous people and continues to apply in the community.

Long period after Indonesian independence, the adoption itself never been set officially. It makes no clear rules of adoption procedures in Indonesia .

Written norm about adoption is on the Circular Letter of Ministry of Justice Law and Regulations Number JHA I / I / 2 of 1978 about Procedure of Adoption Indonesian citizen by Foreign Nationals. This letter is addressed to all Notaries, Deputy Notaries, Temporary Notary Representatives, and Substitute Notaries throughout Indonesia. It is due to the adoption in Indonesia has received public attention due to some reasons as follows:

1) There are no requirements for adoption between countries that provide good guarantees for the welfare of the foster child.

2) The legality of the adoption procedure is sometimes questioned by the governments of other countries whose citizens adopt Indonesian children.

3) There is no similar regulation of adoption procedures. 
In this circular letter, it is stipulated that the adoption of Indonesian citizens by foreign nationals can only be conducted by means of a District Court ruling and it is not justified if foster the child is conducted with notary act legalized by the District Court. Applications for international adoption (inter-country adoption) must be filed at the District Court in Indonesia where the child to be adopted resides. The foster parents must reside or be in Indonesia, the Petitioner must appear before the judge himself that the foster parent is truly capable to be foster parent, and based on the laws and regulations in his country have permission to adopt a child. [10]

The Supreme Court issued Circular Letter of the Supreme Court (SEMA) Number 6 of 1983 concerning Revision of Circular Number 2 of 1983 about Revision of Circular Number 2 of 1979. According to the provisions of SEMA Number 6 of 1983 about Revision of Circular Number 2 of 1979 which regulates the Procedure for Adoption of Children filed by District Court determines that:

1) The adoption of children of Indonesian citizens by foreign nationals is an Ultimum Remedium, because of the aspects of national political and cultural security.

2) The adoption of Indonesian citizens by foreign nationals must be conducted based on a court decision.

3) The conditions that must be fulfilled both from the side of the foster parents, are as follows:

[1] The foreign foster parents must be domiciled and work permanently in Indonesia for at least 3 years;

[2] Prospective foster parents get permission to adopt a child of an Indonesian citizen;

[3] Adoption is carried out through a social foundation that has a license to operate in the field of adoption;

[4] Single parent adoption is not allowed.

4) Requirements that must be met by adopted children:

[1] The age of the prospective adopted child has not reached the age of 5 years;

[2] The child is permitted to be adopted as an adopted child by the Minister of Social Affairs or other appointed official.

Given that the legislation in the field of children is insufficient, this letter is the shortcut to regulate adoption in Indonesia, especially the adoption of foreign children by Indonesian citizens and vice versa. The Circular Letter of Supreme Court Number 6 of 1983 does not allow private adoption, but must go through a social foundation with license to engage in adoption. Moreover, in inter-country adoption, it is along with the permission of the Minister of Social Affairs and with a court order.

The law that giving legal basis for adopting is Law Number 4 of 1979 on Child Welfare. Article regulating adoption is Article 12 that states: (1) adoption of children according to customs and habits is conducted by giving priority to child welfare, (2) the interests of the welfare of children themselves in paragraph one must be regulated further by a government regulation and (3) the adoption of children for the children welfare who conducted beside customs and habits, based on Invitation Legislation.

However, the Child Welfare Law itself does not regulate adoption, so adoption is still conducted in many ways. In 1989 the Government ratified the Convention of the Rights of The Child (CRC). One common spirit of CRC is that adoption is the ultimate remedium and only in the best interest of the child.

Another law that regulates child adoption is Law Number 23 of 2002 concerning Child Protection that regulates child adoption in Articles 39 to 41.This law is arguably the most comprehensive adoption of children. The items for regulating children in the three articles are as follows:

1) Adoption can only be done in the best interest of the child.

2) Adoption of children is carried out based on local customs and statutory provisions. 
3) Adoption does not break the blood relationship between the child and the biological parents.

4) The stipulation that children and foster parents must have the same religion.

5) Adoption of children by foreign nationals can only be done as a last resort.

6) Foster parents are obliged to inform their adopted children about their origins and biological parents, with due regard to the readiness of the child concerned.

\section{Application of Law in Inter Country Adoption in Indonesia The Adoption Case for Tristan}

A case of international adoption in Indonesia that had become a problem was the adoption of Tristan . This case began with the adoption of a baby named Erwin who was born on June 26, 2001. Erwin is Indonesian. He was adopted by husband and wife Joseph Dowse (Irish citizen). They expected to have baby boy, but still do not have. Therefore, while assigned to Jakarta, Joseph Dowse tried to find information about the possibility of adopting an Indonesian boy .

Erwin was obtained by Joseph Dowse from a person as intermediary named Rosdiana. Joseph Dowse then applied for the adoption of a foreign national child to the Irish Court. The Irish Adoption Council has recognized Erwin's adoption - later named Tristan Dowse - as the son of husband and wife Joseph Dowse. Since the adoption was legalized in Ireland, the Irish government also granted Tristan Irish citizenship, also his rights to nurture and the rights to inheritance later.

Eighteen months later, Mrs. Joseph Dowse is pregnant a boy. The family then no longer wanted Tristan Dowse as foster child. Tristan Dowse was then handed over to the Emmanuel Orphanage in Bogor. The case of Tristan Dowse finally became an issue for Irish public after the local media reported the request to cancel the adoption by the husband and wife Joseph Dowse. But an Irish court rejected a request to remove Tristan Dowse's name from the list of foreign foster children.

The High Court in Dublin, ruled that Joseph and Lala had violated their constitutional duties as parents and had to provide for Tristan Dowse until he was 18 years old. They will have to pay a total of $€ 20,000$ (equivalent to IDR 221 million) and a further $€ 350$ (three hundred and fifty Euros or equivalent to IDR 3.87 million) per month until Tristan Dowse turns 18. The High Court also ordered that Tristan Dowse be removed from the Foreign Adoption List maintained by the Irish Adoption Board. This boy will retain Irish citizenship and inheritance rights to Joseph and Lala's property. Based on this case, it appears that the adoption of a child named Erwin as known as Tristan Dowse was not conducted based on the applicable regulations. In addition, based on the aspects of applicable law at the time, the Child Welfare Law, Convention on the Rights of the Child, and the Circular Letter of Supreme Court Number 6 of 1983, the adoption did not meet the provisions.

Tristan is an Indonesian citizen in Indonesia, so the Indonesian law should apply to this adoption. Based on the part of Circular Letter Explanation Number 6 of 1983 states that the definition of the domicile of the child is: "The place where the child is to be raised because following the residence of his parents".[17] The objective is the District Court investigate the situation of the child in order to protect the child's interests, guided by principles that have been well accepted in the European Convention on The Adoption of Children (The Hague Adoption Convention, 1965). Thus, the application for the adoption of Indonesian citizens by foreign nationals should be submitted to the Indonesian court. The adoption in 2001 turned out to be submitted to an Irish court. Based on the aspect of international Civil Law doctrine, an application to an Irish court can be justified, because Joseph Dowse is an Irish citizen. Therefore the law chosen also qualifies, because there is an element of a strong linkage point between Joseph Dowse and Ireland, because he is an Irish citizen. Meanwhile, this proposal is an effort to neglect Tristan's rights and interests as foster child. 
Tristan's adoption is also a private adoption, and not through the Social Foundation which is engaged in adoption. This is contrary to the provisions of the Circular Letter of Supreme Court Number 6 of 1983. It is also possible that the adoption without going through a permit from the authorized institution to grant an inter-country adoption permit.

According to the doctrine of international law, concerning that the adoption is legal action, the adoption should be done based on the place where acts of law took place (principle of lex loci celebrationis/lex loci actus), namely in Indonesia. This is based on the provisions of Article 18 Algemene Bepalingen van Wetgeving (AB) which determines: (1) the form of each action is assessed according to the laws of the State and the place where the act was committed and (2) in order to implement this and previous articles, the attention to the differences of law between Europeans and Indonesians is needed.

Based on the point of view of adoption reasons, Tristan's adoption is not in the best interest of child, as mandated by the Circular Letter of Ministry of Justice Law and Regulations and the Convention on the Rights of the Child. This is evident by the fact that when his wife was pregnant a boy, the foster parents then handed Tristan over to the orphanage. They also filed a cancellation of the inter-country adoption to the Court where they submitted their application for adoption. Therefore, it is fitting that the Dublin High Court ruled that Joseph and Lala had violated their constitutional duties as parents and had to provide for Tristan Dowse until he was 18 years old. Tristan's rights to Irish citizenship was not abolished and gave Tristan inheritance rights. This is definitely to make it easier if one day Tristan takes care of the payment of nurturing rights and inheritance rights.

\section{Conclusion}

Based on the description above, it can be concluded that the implementation of adoption of two countries where the Tristan case was not relevant with the provisions of the applicable law at that time. Unclear legal provisions and procedures for adoption, provisions that are only administrative juridical provisions allow people to violate existing provisions. At the end of the day, the case of inter-country adoption was not conducted in the best interest of child, due to the subjective factor of foster parents' desires was more dominant than the goal of providing a better future for the foster child.

\section{Reference}

Detiknews. (2006). The adoption process of Indonesian by froreign nationals: The study case of Tristan Dowse, http://lib.ui.ac.id/file?file=pdf/abstrak-111274.pdf, access on June 16, 2020. Detik.news., February 25, 2006, Social Department observe the Irish Court on verdict for Tristan, https://news.detik.com/berita/d-547331/depsos-awasi-putusanpengadilan-irlandia-untuk-tristan, access on June 16, 2020.

Pandika, R. (2012). Hukum Pengangkatan Anak. Jakarta: Sinar Grafika.

Sudiyat, I. (1981). Hukum Adat, Sketsa Asas. Yogyakarta: Liberty Press.

Sumiarni, M. E. \& Halim, C. (2000). The Series of Legal Protection on Children Number 1, Legal Protection on Children Based on Family Law. Universitas Atma Jaya Yogyakarta Press.

The Circular Letter of Ministry of Justice Law and Regulations NumberJHA I/I/2 Tahun 1978 about the procedure of adopting Indonesian child by foreign nationals.

The Circular Letter of Supreme Court (SEMA) Number 6 of 1983 about the Revision of the Circular Letter Number 2 of 1983 about the the Revision of the Circular Letter No 2 of 1979 about the Procedure of Adopting Children Officially by District Court.

The resume by Independentie (newspaper), 8 February 2009, The curious case of Tristan Dowse, https://www.independent.ie/life/family/mothers-babies/the-curious-case-oftristan-dowse-26512267.html, access on June 22, 2020. 